\title{
DESCRIPTION OF FINGERPRINT PATTERNS OF BATAK TOBA TRIBE AND MALAY TRIBE BASED ON GENDER IN COASTAL AREAS, BARUS DISTRICT
}

\author{
Binsar H Lubis ${ }^{\mathrm{a}}$, Surjit singh ${ }^{\mathrm{b}}$, Ismurizzal ${ }^{\mathrm{c}}$, Abdul Gafar ${ }^{\mathrm{d}}$, Dessy Harianja ${ }^{\mathrm{e}}$ \\ a binsarhalomoanlubis86@gmail.com
}

Departemen Ilmu Kedokteran Forensik dan Medikolegal RSUP H Adam Malik-Fakultas Kedokteran

Universitas Sumatera Utara Medan - Indonesia

\begin{abstract}
Background: Indonesian society is a pluralistic society. The plurality of Indonesian society consists of various ethnic groups, religions, races, and languages. ${ }^{1}$ Indonesia has hundreds of ethnic names, even thousands if it is broken down into sub-tribes. Two of them are Batak and Malay. ${ }^{19}$ There are different biological characteristics between Batak and Malay ethnic groups, such as hair shape and color, nose shape, iris color and eye slit location. So it is possible that these two ethnic groups (Batak Toba and Malay) also have different fingerprint patterns. One of the biological characteristics possessed by humans is fingerprints. Fingerprints in humans are not influenced by the external environment except the environment in the womb. Genetics plays a very important role in the formation of fingerprints, because fingerprints are influenced by polygen elements
\end{abstract}

Method: This research is descriptive with a quantitative approach to the Batak Toba and Malay communities in the coastal area of Barus District, Central Tapanuli Regency, carried out in the period from 1 August 2021 to 30 September 2021. The sample in this study were all people living in Barus District. Toba Batak and Malay tribes using purposive sampling method as many as 30 Toba Batak ethnic people and 30 Malay ethnic people who meet the inclusion and exclusion criteria.

Discussion: Based on research conducted by recording the fingerprints of 10 (ten) fingers from each respondent in the Barus community, the Batak tribe, 26 men and 4, then the Malay ethnic group. 26 men and 4 women, the fingerprint pattern of the Barus community was obtained with details on the Batak Toba tribe, the male gender with an arch pattern of 48 fingers (18\%), a loop pattern of 151 fingers (58\%) and a Whorl pattern of 61 fingers ( $23.5 \%)$. While the fingerprint pattern of the Barus community with details on the female Batak Toba tribe with an arch pattern of 10 fingers ( $25 \%$ ), a loop pattern of 26 fingers (65\%) and a Whorl pattern of 4 fingers (10\%). The fingerprint pattern of the Barus community with details on the male ethnic Malays with an arch pattern of 50 fingers (19.2\%), a loop pattern of 154 fingers $(59.3 \%)$ and a Whorl pattern as many as 56 fingers $(21.5 \%)$. Then the fingerprint pattern of the Barus community with details on the female Malay tribe with an arch pattern of 7 fingers (17.5\%), a loop pattern of 27 fingers (967.5\% and a Whorl pattern of 6 ( $15 \%)$.

Conclussion: From the Batak Toba and Malay tribes, both male and female, the most frequent fingerprint pattern is the loop pattern, followed by the whorl pattern and the least is the arch pattern.

Keyword: Fingerprint pattern, loop pattern, Batak tribe, Malay tribe, Barus sub-district 


\section{PRELIMINARY}

Indonesian society is a pluralistic society. The plurality of Indonesian society consists of various ethnic groups, religions, races, and languages.1 Indonesia has hundreds of ethnic names, even thousands if it is broken down into sub-tribes. Two of them are Batak and Malay. ${ }^{19}$

Barus is one of the places that played a very important role in the beginning of civilization, the entry of Batak culture, the birth of the Parmalim Batak religion which is the religion of the ancestors of the Batak tribe. Barus sub-district is 290 kilometers from the city of Medan, the capital of North Sumatra. Barus is a historical place and is currently one of the destinations for religious tourism in North Sumatra.2 Coastal cultural values have been embedded in people's lives, this can be seen from the variety of cultures and languages used by people everyday.

Fingerprint is one of the human identities that cannot be replaced or changed. In addition, it is also from fingerprints that a person can be recognized. No human in this world has the same fingerprint. There are different biological characteristics between Batak and Malay ethnic groups, such as hair shape and color, nose shape, iris color and eye slit location. So it is possible that these two ethnic groups (Batak Toba and Malay) also have different fingerprint patterns. One of the biological characteristics possessed by humans is fingerprints. Fingerprints in humans are not influenced by the external environment except the environment in the womb. Genetics plays a very important role in the formation of fingerprints, because fingerprints are influenced by polygen elements

Previous research by Karlina Purausari who conducted research in Madiun in 2017 concluded that eleven ethnic groups were found, ten ethnic groups had a higher percentage of loop patterns than other patterns, namely the Javanese (60.4\%), Dayak (69\%), Flores $(50.59 \%)$, Batak (56\%), Lampung (90\%), Balinese (70\%), Mentawai (50\%), Banjar (60\%), Madurese (100\%), and Betawi (70\%). The Minang tribe has a higher percentage of the whorl pattern than other patterns, which is $70 \% .^{18}$

\section{DERMATOGLIFI}

Dermatoglyphs are epidermal ridges on the palmar and plantar fingers. Dermatoglyphics is a branch of science that studies the lines of skin found on the fingers and toes of humans and other mammals. Research on fingerprints continues to be developed, until it is found that fingerprints can be used as an identification tool in the fields of anthropology, criminology, and medicine. ${ }^{9}$ 
Fingerprint is one of the human identities that cannot be replaced or changed. In addition, it is also from fingerprints that a person can be recognized.

In 1892 Galton classified the fingertip tendril pattern into 3 types, namely: 1) Arch type (A) 2) Ulnar Loop type (LU) and Radial Loop type (LR) 3) Whorl type (W). The primary tendril formation stage occurs around week 10 to week 17 after fertilization, while the secondary tendril formation stage occurs at week 18 to week 25 .

Forensic identification is an effort made with the aim of helping investigators to determine a person's identity. The role of forensic medicine is in the identification of unknown bodies, damaged, decomposed, charred bodies, mass accidents, natural disasters and riots that resulted in many deaths and pieces of human bodies or skeletons.

So far, no one has conducted research on how to describe fingerprint patterns in the Batak Toba and Malay ethnic groups based on gender in the coastal area of the Barus sub-district, therefore, the authors are interested in conducting this research.

\section{RESEARCH METHODOLOGY}

This research is descriptive with a quantitative approach to the Toba Batak and Malay tribes in the coastal area of Barus District, Central Tapanuli Regency, carried out in the period from August 1, 2021 to September 30, 2021.

Based on the above background, the formulation of the problem in this study is to see the description of fingerprint patterns in the Batak Toba and Malay ethnic groups based on gender in the coastal area of the Barus sub-district.

The objectives of this study are: To find out the description of fingerprint patterns in the Toba Batak and Malay communities in the coastal area of Barus sub-district based on gender.

The sample in this study were all people living in Barus District, Batak Toba and Malay tribes. This research was conducted using a purposive sampling method, namely, taking samples using certain considerations (Sugiyono, 2002). With a sample of 30 people of Toba Batak ethnicity and 30 people of Malay ethnicity. In this case, sampling is based on certain characteristics, traits, or characteristics, namely those listed in the inclusion and exclusion criteria.

Inclusion Criteria

(1) People living in Barus sub-district. (2) Toba Batak and Malay 2 generations, there is no mixing of both men and women. (3) Have complete fingers. (4) Have normal hand fingerprints. (5) Good fingerprint results. (6) Willing to be a respondent

Exclusion Criteria: 
(1) There are lesions on the fingerprints. (2) Never had a surgery that damaged fingerprints. (3) Have had finger amputation surgery. (4) There is a congenital deformity of the fingers. (5) There is a deformity of the fingers after the accident. (6) Not willing to be a respondent.

Research variable

The variables studied were: (1) People who live in Barus District, Toba Batak tribe, are male and female. (2) The people who live in Barus District are ethnic Malays, male and female.

\section{RESEARCH RESULT}

Based on research conducted on September 1, 2021 in Barus sub-district, Tapanuli Regency, 10 finger prints are being recorded from each respondent in the Barus community of the Batak tribe, 26 men and 26 female respondents. 4 people, then 26 men in the Malay tribe and 4 women. The fingerprint pattern was obtained with the following details for the male Batak Toba tribe with an arch pattern of 48 fingers, a loop pattern of 151 fingers and a Whorl pattern of 61 finger. While the fingerprint pattern of the Barus community is detailed on the female Batak Toba tribe with 10 fingers arch pattern, 26 finger loop pattern and 4 finger Whorl pattern. The fingerprint pattern of the Barus community consists of male ethnic Malays with 50 arches, 154 loops and 56 Whorl patterns. Then the fingerprint pattern of the Barus community with details on the female Malay ethnic group with an arch pattern of 7 fingers, a loop pattern of 27 fingers and a Whorl pattern of 6 fingers.

The Fingerprint Pattern of the Barus Community in the Toba Batak Tribe, Male Gender

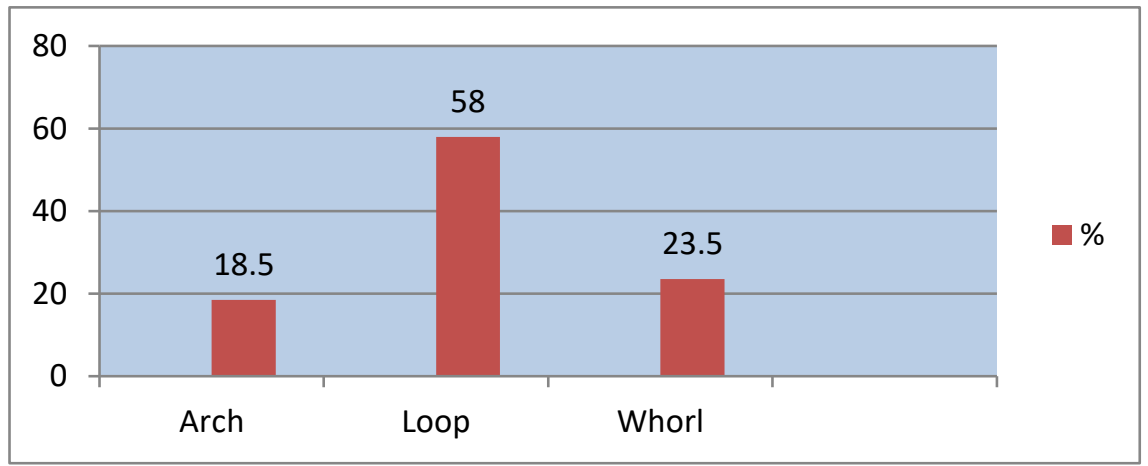

Diagram 1. Fingerprint Patterns of the Barus Community in the Toba Batak Tribe, Male Gender 
The Fingerprint Pattern of the Barus Community in the Toba Batak Tribe Gender is Female

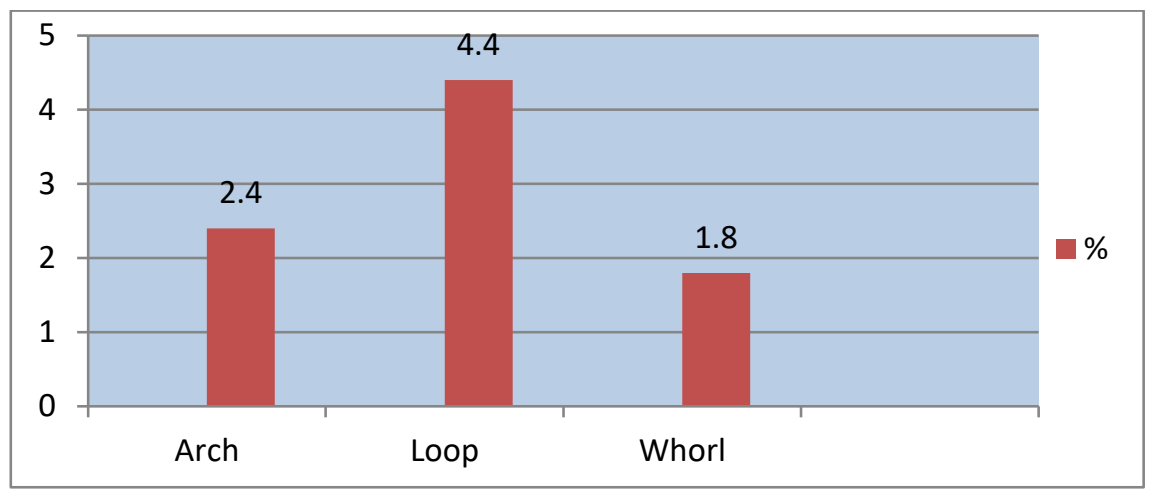

Diagram 1. Fingerprint Patterns of the Barus Community in the Toba Batak Tribe, Male Gender

The Fingerprint Pattern of the Barus Community in the Toba Batak Tribe Gender is Female

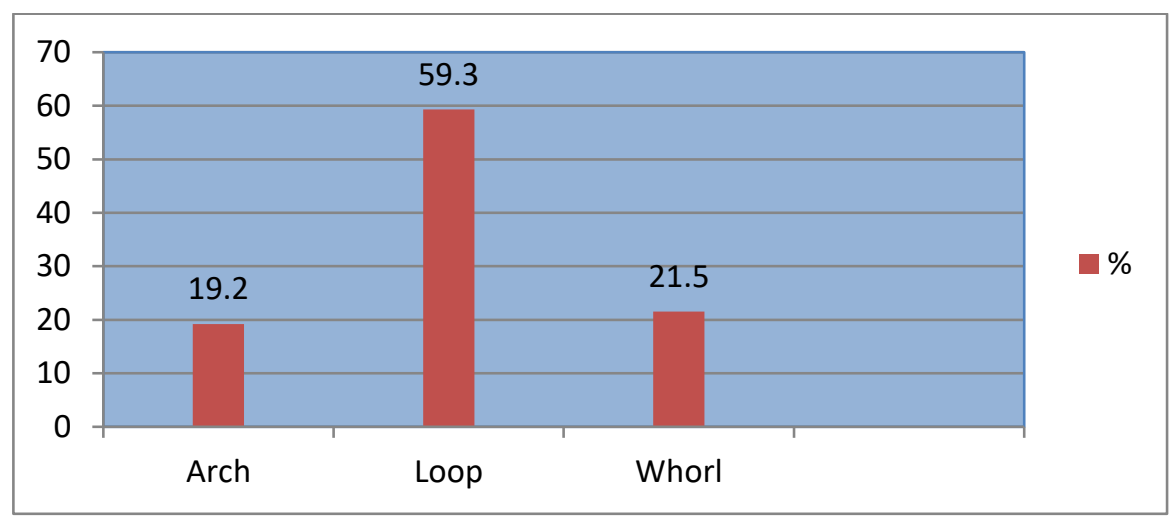

Diagram 3. Fingerprint Patterns of the Barus Community in the Malay Ethnic Male Gender The Fingerprint Pattern of the Barus Society of the Malays, Gender is Female

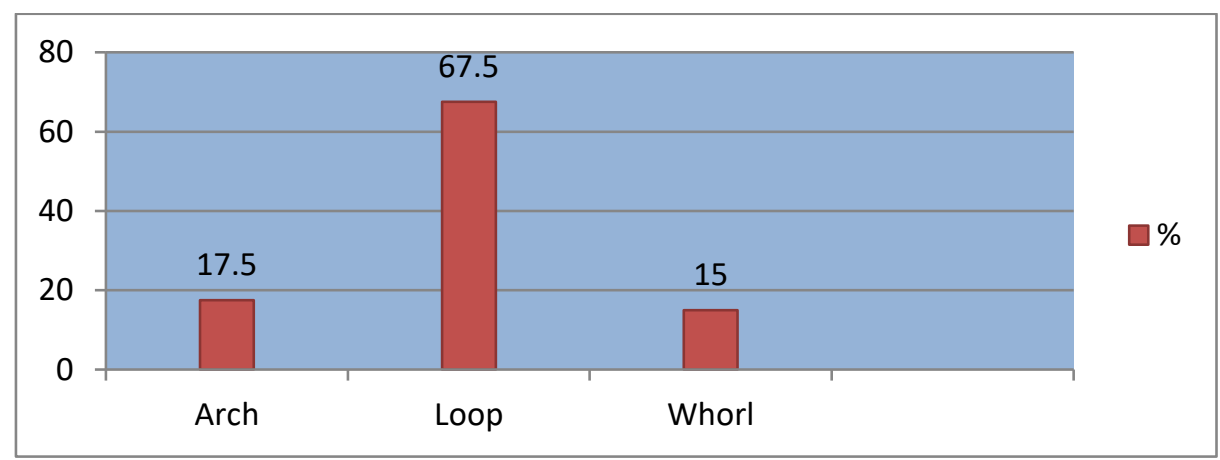

Diagram 4. Fingerprint Patterns of the Barus Community in the Malay Ethnic Gender of Women. 


\section{DISCUSSION}

Based on research conducted by recording the fingerprints of 10 (ten) fingers from each respondent in the Barus community, the Batak tribe, 26 (twenty six) men and 4 (four) women, then the Malay ethnic group. 26 (twenty six) men and 4 (four) women, the fingerprint pattern of the Barus community was obtained with details on the Batak Toba tribe, the male gender with an arch pattern of 48 (forty eight) fingers. with a percentage of $18 \%$, a loop pattern of 151 (one hundred and fifty one) fingers with a percentage of $58 \%$ and a Whorl pattern of 61 (sixty one) fingers with a percentage of $23.5 \%$. While the fingerprint pattern of the Barus community with details on the female Batak Toba tribe with an arch pattern of 10 (ten) fingers with a percentage of $25 \%$, a loop pattern of 26 (twenty six) fingers with a percentage of 65 and a Whorl pattern of 4 (four) fingers. finger with a percentage of $10 \%$. The fingerprint pattern of the Barus community with details on the male ethnic Malays with an arch pattern of 50 (fifty) fingers 19.2\%, a loop pattern of 154 (one hundred and fifty four) fingers with a percentage of $59.3 \%$ and a Whorl pattern as many as 56 (fifty six) fingers $21.5 \%$. Then the fingerprint pattern of the Barus community with details on the female Malay tribe with an arch pattern of 7 (seven) fingers 17.5\%, a loop pattern of 27 (twenty seven) fingers with a percentage of $67.5 \%$ and a Whorl pattern of 6 (seven) fingers. six) fingers with a percentage of $15 \%$.

\section{The Fingerprint Pattern of the Barus Community in the Toba Batak Tribe, Male Gender}

The fingerprint pattern of the Barus community in the Batak Toba tribe, male sex, obtained the most patterns, namely loops as many as 151 (58\%). The frequency distribution of the fingerprint pattern of the Barus community in the male Batak tribe is presented in tabular form.

Table 4.1. Frequency Distribution of Batak Toba male fingerprint pattern

\begin{tabular}{ccc}
\hline $\begin{array}{c}\text { Fingerprint } \\
\text { Pattern }\end{array}$ & \multicolumn{2}{c}{ Toba Batak Tribe } \\
\cline { 2 - 3 } Arch & Sum & $\%$ \\
Loop & 48 & 18,5 \\
Whorl & 151 & 58 \\
& 61 & 23,5 \\
\hline Total & $\mathbf{2 6 0}$ & $\mathbf{1 0 0}$ \\
\hline
\end{tabular}


Based on research conducted by recording the fingerprints of 10 (ten) fingers from each respondent in the Barus community, the fingerprint pattern of the Barus community with details on the Batak Toba tribe, the male gender with an arch pattern of 48 (forty eight) fingers with a percentage of $18.5 \%$, loop pattern as many as 151 (one hundred and fifty one) fingers with a percentage of $58 \%$ and Whorl pattern as many as 61 (sixty one) fingers with a percentage of $23.5 \%$. Judging from the overall data, the loop fingerprint pattern is more than the arch and whorl fingerprint pattern with a percentage of $58 \%$.

\section{The Fingerprint Pattern of the Barus Community in the Toba Batak Tribe Gender is Female}

The fingerprint pattern of the Barus community in the female Batak tribe obtained the most pattern, namely loops as much as $65 \%$. The frequency distribution of the fingerprint pattern of the Barus community in the female Batak ethnic group is presented in tabular form.

Table 4.2. Frequency Distribution of Toba Batak women's fingerprint pattern

\begin{tabular}{ccc}
\hline $\begin{array}{c}\text { Fingerprint } \\
\text { Pattern }\end{array}$ & \multicolumn{2}{c}{ Toba Batak Tribe } \\
\cline { 2 - 3 } Arch & Sum & $\%$ \\
Loop & 10 & 25 \\
Whorl & 26 & 65 \\
& 4 & 10 \\
\hline Total & $\mathbf{4 0}$ & $\mathbf{1 0 0}$ \\
\hline
\end{tabular}

Based on research conducted by recording fingerprints of 10 (ten) fingers from each respondent in the Barus community, the fingerprint pattern of the Barus community with details on the Batak Toba tribe, the female gender with an arch pattern of 10 (ten) fingers with a percentage of $25 \%$, loop pattern as many as 26 (twenty six) fingers with a percentage of $65 \%$ and a Whorl pattern of 4 (four) fingers with a percentage of 10\%. Judging from the overall data, the loop fingerprint pattern is more than the arch and whorl fingerprint pattern with a percentage of $65 \%$.

\section{The Fingerprint Pattern of the Barus Community in the Malays, Male Gender}

The fingerprint pattern of the Barus community in the male Batak tribe obtained the most patterns, namely loops as many as 154 (59.2\%). The frequency distribution of the Barus community's fingerprint pattern in the male Malay ethnic group is presented in tabular form. 
Table 4.3. Frequency Distribution of Malay male fingerprint pattern

\begin{tabular}{ccc}
\hline $\begin{array}{c}\text { Fingerprint } \\
\text { Pattern }\end{array}$ & \multicolumn{2}{c}{ Malay tribe } \\
\cline { 2 - 3 } Arch & Sum & $\%$ \\
& 50 & 19,2 \\
Loop & 154 & 59,2 \\
Whorl & 56 & 21,6 \\
\hline Total & $\mathbf{2 6 0}$ & $\mathbf{1 0 0}$ \\
\hline
\end{tabular}

Based on research conducted by recording the fingerprints of 10 (ten) fingers from each respondent in the Barus community, the fingerprint pattern of the Barus community with details on the Malay tribe, the male gender with an arch pattern of 50 (fifty) fingers with a percentage of 19.2 $\%$, loop pattern as many as 154 (one hundred and fifty four) fingers with a percentage of $59.2 \%$ and Whorl pattern as many as 56 (fifty six) fingers with a percentage of $21.6 \%$. Judging from the overall data loop fingerprint patterns are more than arch and whorl fingerprint patterns with a percentage of $59.2 \%$.

\section{The Fingerprint Pattern of the Barus Society of the Malays, Gender is Female}

The fingerprint pattern of the Barus community in the male Batak tribe obtained the most patterns, namely loops of $27(67.5 \%)$. The frequency distribution of the fingerprint pattern of the Barus community in the male Batak tribe is presented in tabular form.

Table 4.4. Frequency Distribution of Malay women's fingerprint pattern

\begin{tabular}{ccc}
\hline $\begin{array}{c}\text { Fingerprint } \\
\text { Pattern }\end{array}$ & \multicolumn{2}{c}{ Malay tribe } \\
\cline { 2 - 3 } Arch & Sum & $\%$ \\
& 7 & 17,5 \\
Loop & 27 & 67,5 \\
Whorl & 6 & 15 \\
\hline Total & $\mathbf{4 0}$ & $\mathbf{1 0 0}$ \\
\hline
\end{tabular}


Based on research conducted by recording the fingerprints of 10 (ten) fingers from each respondent in the Barus community, the fingerprint pattern of the Barus community with details on the Malay ethnic group, female sex with an arch pattern of 7 (seven) fingers with a percentage of $17.5 \%$, pattern loops of 27 (twenty seven) fingers with a percentage of $67.5 \%$ and a Whorl pattern of 6 (six) fingers with a percentage of $15 \%$. Judging from the overall data, the loop fingerprint pattern is more than the arch and whorl fingerprint pattern with a percentage of $67.5 \%$.

The results of this study when separated by gender, the results obtained from the Batak Toba and Malay tribes in male and female individuals obtained the same results, namely the highest percentage was found in the loop pattern in the Batak Toba tribe, male sex 58\% and female gender. $65 \%$, then arch pattern $18.5 \%$ in male and $25 \%$ and the smallest is whorl $23.5 \%$ in male and $10 \%$. And in the Malay tribe, the male gender is $59.3 \%$ and the female gender is $67.5 \%$, then whorl is $21.5 \%$ in the male gender and $15 \%$ and the smallest is the male arch pattern $19.2 \%$ and $17.5 \%$ in women.

\section{CONCLUSION}

The fingerprint pattern of the Barus community in the male Batak Toba tribe is dominated by a loop pattern, followed by a whorl pattern and at least an arch pattern.

1. The fingerprint pattern of the Barus community in the female Batak Toba tribe is dominated by a loop pattern, followed by an arch pattern and at least a whorl pattern.

2. The fingerprint pattern of the Barus community in the male Malay ethnic group is dominated by a loop pattern, followed by a whorl pattern and at least an arch pattern.

3. The fingerprint pattern of the Barus community in the female Malay ethnic group is dominated by a loop pattern, followed by an arch pattern and at least a whorl pattern.

4. Of the Batak Toba and Malay tribes, both male and female, the most frequent fingerprint pattern is the loop pattern, followed by the whorl pattern and the least is the arch pattern.

\section{SUGGESTION}

1. It is recommended to do further research with a larger number of samples and the number of other tribes.

2. It is recommended that further research be conducted with a larger number of samples and the same number of male and female sexes.

3. It is recommended to do further research with a more accurate fingerprint retrieval tool.

4. It is recommended to conduct a comparison study of the results with the e-KTP recording data.

5. Increase the level (degree) of fingerprints that are checked to be more specific. 


\section{ETHICAL CLEARANCE}

This research was conducted after obtaining approval from the Ethics Committee of the Faculty of Medicine, University of North Sumatra, Medan with No: 769/KEP/USU/2021

\section{REFERENCES}

Arif, D.B. (2013). Membingkai Keberagaman Indonesia: Perspektif Pendidikan Kewarganegaraan Program Kurikuler. Penguatan Kompetensi Calon Praktikan PPL Program Studi PPKN. Universitas Ahmad Dahlan Yogyakarta.

Rusman Siregar. (2017) Barus, Kota Islam Pertama di Indonesia. Available from: https://daerah.sindonews.com/berita/1249657/29/barus-kota-islam-pertama-diindonesia

Misri A. Muchsin. (2017). Barus Dalam Sejarah: Kawasan Percaturan Politik, Agama dan Ekonomi Dunia. ADABIYA, Volume 19 No. 1 Februari 2017.

Simamora,Nubaiti. (2018). Hubungan Kelompok Etnik Batak Toba dengan Kelompok Etnik Pesisir (Studi Kasus di Kota Barus, Tapanuli Tengah, Sumatera Utara).

Fanani Hidayati. (2015). Variasi Pola Sidik Jari pada Populasi Jawa dan Papua. Departemen Antropologi, FISIP, Universitas Airlangga, Surabaya.

Veneza, A. Dewi A. (2013). Fungsi Sidik Jari Dalam Mengidentifikasi Korban dan Pelaku Tindak Pidana. Fakultas Hukum Universitas Hasanuddin.

Markas Besar Kepolisian Negara Republik Indonesia Pusat kedokteran dan Kesehatan. Pedoman tentang Penatalaksanaan Disaster Victim Identification (DVI) bagi POLRI Edisi Revisi. PUSDOKKES POLRI. Jakarta; 2010. H.15, 47-51

Pradana, I,H. (2015). Klasifikasi Citra Sidik Jari Berdasarkan Enam Tipe Pattern Menggunakan Metode Euclidean Distance. Available from: https://docplayer.info/60350252-Skripsiklasifikasi-citra-sidik-jari-berdasarkan-enam-tipe-pattern-menggunakan-metodeeuclidean-distance-fingerprint-classification-image.html.

Permatasari, I. (2019). Hubungan Sidik Jari Kaki dengan Prestasi Akademik Pada Mahasiswa Fakultas Kedokteran Universitas Diponegoro.

IDN Times Sejarah Sidik Jari, Salah Satu Fitur Manusia yang Penting. Available from: https://www.idntimes.com/science/discovery/yohana-belinda-1/sejarah-sidik-jari/5

Jaya H, Triwani , Yasin H, Marwoto J, Lukman. (2014. Hubungan Pola Dermatoglifi dengan Hipertensi Essensial ). Jurnal Keperawatan Soedirman (The Soedirman Journal of Nursing), Volume 9, No.2.

RS Fuadi. (2019). Available from: http://repository.unissula.ac.id/16017/5/bab\%20I.pdf. 
Dahoklory,M. (2020). Perancangan Integrated Smart Presence dengan Memanfaatkan Finger Print Berbasis Prototype. Available from:file:///C:/Users/WIN10/Downloads/331Article\%20Text-805-1-10-20201101.pdf.

Library Binus. (2013). Available from: http://library.binus.ac.id/eColls/eThesisdoc/Bab2/2013-100616-IF\%20Bab2001.pdf.

SidikJariIndonesia. (2016). Available from: https://www.sidikjariindonesia.com/sejarah-risetanalisa-sidik-jari.

Sianipar, MC. (2018). Identifikasi dan Klasifikasi Sidik Jari Level 2 Menggunakan Metode Minutiate. Fakultas Ilmu Komputer dan Teknologi Informasi Universitas Sumatera Utara.

Amir A. Rangkaian Ilmu Kedokteran Forensik. Edisi Kedua. Bagian Ilmu Kedokteran Forensik Dan Medikolegal Fakultas Kedokteran USU Medan. Medan; 2010. H. 178-203

https://id.wikipedia.org/wiki/Barus,_Tapanuli_Tengah\#Demografi

Karlina Purbasari. VARIASI POLA SIDIK JARI MAHASISWA BERBAGAI SUKU BANGSA DI KOTA MADIUN. urnal Florea Volume 4 No. 2, November 2017

https://www.bps.go.id/news/2015/11/18/127/mengulik-data-suku-di-indonesia.html 